\title{
Pengaruh Penambahan Tepung Jahe Merah (Zingiber Officinale Var Rubrum) Dalam Pakan Ayam Broiler Terhadap Pertambahan Bobot Badan, Konversi Pakan dan Konsumsi Pakan
}

\author{
The Effect Of Red Ginger Flour (zingiber officinale var rubrum ) As Herbal Feed \\ Additive On Feed Comsumption, Daily Weight Gain And Feed Conversion Ratio Of \\ Broiler \\ Fitria Sekar Ningsih ${ }^{1}$, Novi Eka Wati ${ }^{1}$, dan Miki Suhadi ${ }^{1}$ \\ 'Program Studi Peternakan Fakultas Peternakan Universitas Tulang Bawang Lampung \\ Corresponding e-mail: Fitriasekarningsih@gmail.com
}

\begin{abstract}
This aim of study was to determined effect of red ginger flour (Zingiber Officinale Var Rubrum) as herbal feed additive in Broiler Chiken on feed comsumption, daily body weight gain and feed conversion ratio.The research was conducted on September - Oktober 2020 at Gisting Atas Village, Gisting District, Tanggamus Regency, Lampung. The experiment used 80 unisex Broiler aged 1 week. They were feed a ration with control ration $+0 \%$ red ginger flour $(\mathrm{P} 0)$, control ration $+0,25 \%$ red ginger flour $(\mathrm{P} 1)$, control ration $+0,5 \%$ red ginger flour $(\mathrm{P} 2)$, control ratio $+0,75 \%$ red ginger flour $(\mathrm{P} 3)$ during 20 days. The control ration containing $21 \%$ crude protein and $3108 \mathrm{kkal} / \mathrm{kg}$ metabolism energy. The study used a quantitative methods with completely randomized design with 4 treatments and 4 replications. The results showed that the ration had no effect $(\mathrm{P}>0,05)$ on feed comsumption, daily weight gain and conversion ratio. The conclution of the research showed that the addition of level red ginger flour (Zingiber Officinale Var Rubru) until $0,75 \%$ as herbal feed additive in Broiler Chiken no effect on feed comsumption, daily body weight gain and feed conversion ratio.
\end{abstract}

Keywords: Red ginger flour, Broiler, Feed Comsumption, Daily Weight Gain, Feed Conversion Ratio.

\begin{abstract}
ABSTRAK
Penelitian ini bertujuan untuk mengetahui pengaruh tepung jahe merah (Zingiber Officinale Var Rubrum) sebagai pakan tambahan herbal pada Ayam Broiler terhadap konsumsi pakan, pertambahan bobot badan harian dan rasio konversi pakan. Penelitian dilaksanakan pada bulan September - Oktober 2020 di Gisting Atas. Desa, Kecamatan Gisting, Kabupaten Tanggamus, Lampung. Percobaan menggunakan 80 ekor ayam pedaging unisex berumur 1 minggu. Mereka diberi ransum dengan ransum kontrol $+0 \%$ tepung jahe merah (P0), ransum kontrol $+0,25 \%$ tepung jahe merah $(\mathrm{P} 1)$, ransum kontrol $+0,5 \%$ tepung jahe merah (P2), rasio kontrol $+0,75 \%$ tepung jahe merah (P3) selama 20 hari. Ransum kontrol mengandung protein kasar $21 \%$ dan energi metabolisme $3108 \mathrm{kkal} / \mathrm{kg}$. Penelitian menggunakan metode kuantitatif dengan rancangan acak lengkap dengan 4 perlakuan dan 4 ulangan. Hasil penelitian menunjukkan bahwa ransum tidak berpengaruh $(\mathrm{P}>0,05)$ terhadap konsumsi pakan, pertambahan bobot badan harian dan rasio konversi. Kesimpulan penelitian menunjukkan bahwa penambahan kadar tepung jahe merah (Zingiber Officinale Var Rubru) sampai 0,75\% sebagai bahan tambahan pakan herbal pada Ayam Broiler tidak berpengaruh terhadap konsumsi pakan, pertambahan bobot badan harian dan rasio konversi pakan.
\end{abstract}

Kata kunci: Tepung jahe merah, Ayam pedaging, Konsumsi Pakan, Pertambahan Berat Badan Harian, Rasio Konversi Pakan..

\section{PENDAHULUAN}

Peningkatan jumlah penduduk sangat berpengaruh terhadap peningkatan pangan nasional khususnya sumber protein hewani. Salah satu sumber protein hewani yang banyak dikonsumsi oleh masyarakat Indonesia adalah daging Ayam Broiler. Data peningkatan konsumsi Ayam Broiler menurut Ditjen Peternakan Kementan (2019) kekurangan produksi daging tahun 20162019. Jumlah permintaan daging Ayam untuk konsumsi cenderung meningkat sebesar $1,56 \%$ per 
tahun atau 4,69 kg/kap/tahun, sehingga total kebutuhan daging Ayam untuk konsumsi langsung pada tahun 2016 sebesar 1,19 juta ton, tahun 2017 sebesar 1,24 juta ton, tahun 2018 sebesar 1,27 juta ton dan tahun 2019 mencapai 1, 30 juta ton.

Seiring dengan meningkatkanya konsumsi daging Ayam Broiler perlu adanya peningkatan produktivitas Ayam Broiler dengan cara perbaikan kualitas pakan dengan penambahan feed aditif alami yaitu jahe merah (Zingiber officinale var Rubrum), Jahe merah mengandung minyak atsiri dan kurkumin.Minyak atsiri dalam jahe merah yaitu membantu kerja enzim pencernaan sehingga sistem pencernaan bekerja secara optimal dan seiring dengan laju pertumbuhan maka produksi daging Ayam akan naik. Kurkumin berfungsi meningkatkan organ pencernaan Ayam Broiler dengan merangsang keluarnya getah pankreas yang mengandung enzim amylase, lipase dan protease yang berguna untuk meningkatakan pencernaan bahan pakan seperti karbohidrat, lemak protein (Winarto, 2003). Hasil penelitian Herawati (2010) menunjukkan bahwa penambahan fitobiotik jahe merah sebanyak $2 \%$ dari pakan memberikan pengaruh nyata terhadap pertambahan bobot badan, konsumsi ransum dan konversi ransum. Hal ini yang mendorong adanya penelitian tentang penambahan tepung jahe merah (Zingiber officinale var Rubrum) dalam pakan Ayam Broiler terhadap konsumsi pakan, pertambahan bobot badan dan konversi pakan.

\section{Materi Penelitian}

\section{METODELOGI}

Alat yang digunakan dalam penelitian antara lain: timbangan dengan ketelitian $1 \mathrm{~kg}$, wadah pakan, wadah air minum, nampan, lembar pengamatan, camera dan alat tulis. Bahan yang digunakan dalam penelitian ini meliputi 80 ekor Ayam Broiler berumur 1 minggu, yang diberi perlakuan selama 20 hari. Ayam ditempatkan dalam 4 petak kandang sesuai dengan jumlah perlakuan. Setiap petak kandang perlakuan dibagi menjadi 4 bagian sebagai ulangan. Setiap ulangan terdapat 5 ekor Ayam Broiler.

Perlakuan yang diberikan adalah :

Po $=$ pakan basal $+0 \%$ tepung jahe merah

$\mathrm{P} 1$ = pakan basal $+0,25$ tepung jahe merah

$\mathrm{P} 2=$ pakan basal $+0,5 \%$ tepung jahe merah

$\mathrm{P} 3=$ pakan basal $+0,75 \%$ tepung jahe merah

Pakan basal yang digunakan adalah pakan konsentrat merk Surya Feed Sb 11 Super yang diproduksi oleh PT. Japfa Comfeed Indonesia Tbk. Kandungan nutrisi pakan kontrol tersaji pada Tabel 1. 


\begin{tabular}{lc}
\hline \multicolumn{1}{c}{ Nutrisi } & Jumlah \\
\hline Air & $12 \%$ \\
Protein Kasar & $21 \%$ \\
Lemak Kasar & $5 \%$ \\
Serat Kasar & $5 \%$ \\
Abu & $7 \%$ \\
Kalsium & $0,6 \%$ \\
Phospor & $0,5 \%$ \\
Enzym & Phytase \\
Aflatoxin & $50 \mathrm{~g} / \mathrm{kg}$
\end{tabular}

Sumber : PT. Japfa Comfeed Indonesia (2020)

Metode Penelitian

Ayam Broiler berumur 1 minggu diberi perlakuan selama 20 hari. Ayam Broiler diberi perlakuan pada umur 1 minggu sampai umur 4 minggu dengan 1 perlakuan terdapat 5 ekor ayam pada $\mathrm{P} 0=$ tanpa penambahan tepung jahe merah, $\mathrm{P} 1=$ Pakan basal $+0,25 \%$ tepung jahe merah $(0,25 \mathrm{~g} / \mathrm{kg}$ pakan $), \mathrm{P} 2=$ Pakan basal $+0,5 \%$ tepung jahe merah $(0,5 \mathrm{~g} / \mathrm{kg}$ pakan $), \mathrm{P} 3=$ Pakan basal $+0,75 \%$ tepung jahe merah ( $0,75 \mathrm{~g} / \mathrm{kg}$ pakan). Pemberian pakan, dilakukan 2 kali dalam satu hari pada pagi hari pukul 06.00 WIB dan sore hari pada pukul $14.00 \mathrm{WIB}$, penimbangan sisa pakan yang dilakukan setiap pagi dan sore hari, penimbangan bobot badan ayam dilakukan pada awal dan akhir penelitian. Sebelum dilakukan pemberian pakan, pakan ditimbang lalu dicampur dengan tepung jahe merah.

Dan hasil penelitian diuji $\mathrm{F}$ berdasarkan prosedur sidik ragam dan jika terdapat pengaruh pada perlakuan dilanjutkan dengan uji jarak berganda Duncan (UJGD) pada taraf 5\% dengan perangkat lunak SPSS version 17.00 untuk mengetahui pengaruh penambahan tepung jahe merah terbaik.

\section{HASIL PENELITIAN}

\section{Pengaruh Perlakuan Terhadap Konsumsi Pakan}

Hasil Penelitian menunjukan bahwa penambahan tepung jahe merah (Zingiber officinale var Rubrum) pada pakan Ayam Broiler tidak berpengaruh nyata $(\mathrm{P}>0,05)$. Besarnya konsumsi pakan Ayam Broiler yang mendapat perlakuan P0, P1, P2 dan P3 tersaji pada tabel 2.

Tabel 2. Konsumsi Pakan Ayam Broiler dengan Penambahan Tepung Jahe Merah (Zingiber officinale var Rubrum) pada pakan.

\begin{tabular}{ccc}
\hline Perlakuan & Rataan gram/ekor/hari & Standar Deviasi \\
\hline P0 & 128 & 1,85 \\
P1 & 136 & 16,54 \\
P2 & 127 & 1,725 \\
P3 & 127 & 0,12 \\
\hline
\end{tabular}

Rataan konsumsi pakan Ayam Broiler yang diberi perlakuan penambahan tepung jahe 
merah P0, P1, P2 dan P3 tidak berbeda nyata yaitu berturut-turut sebesar 128 gram, 136 gram, 127 gram, 127 gram. Hasil ini menunjukan bahwa penambahan tepung jahe merah pada dosis 0,25\%-0,75\% tidak berpengaruh pada peningkatan konsumsi pakan Ayam Broiler, hal ini diduga karena kandungan kurkumin dan atsiri pada jahe merah yang ditambahkan dalam pakan Ayam Broiler belum berpengaruh pada peningkatan nafsu makan dan kerja enzim pencernaan pada Ayam Broiler. Sejalan dengan penelitian Moorty et al. (2009), menunjukan bahwa penggunaan tepung jahe merah $0,2 \%$ dalam ransum ayam pedaging tidak berpengaruh terhadap konsumsi ransum. Herawati et al. (2006) menyatakan bahwa pemberian tepung jahe merah dalam pakan Ayam Broiler dengan dosis 2,0\% memberikan pengaruh yang relative baik pada konsumsi pakan. Faktor lain yang diduga membuat konsumsi ransum sama pada semua perlakuan yaitu kandungan nutrisi ransum yang digunakan sama. Kateran (2010), berpendapat bahwa kebutuhan gizi unggas berbeda sesuai dengan jenis unggas, bangsa, umur, fase produksi, dan jenis kelamin. Kebutuhan gizi tersebut mencakup protein, asam amino, energi, Ca dan $\mathrm{P}$ serta tingkat konsumsi pakan/ekor/hari.

\section{Pengaruh Perlakuan Terhadap Bobot Badan Harian}

Penambahan tepung jahe merah (Zingiber officinale var Rubrum) pada pakan Ayam Broiler tidak berpengaruh nyata $(\mathrm{P}>0,05)$ terhadap pertambahan bobot badan. Besarnya pertambahan bobot badan ayam Broiler yang mendapat perlakuan P0, P1, P2 dan P3 tersaji pada tabel 3.

Tabel 3. Pertambahan Bobot Badan Harian Ayam Broiler dengan Penambahan Tepung Jahe Merah (Zingiber officinale var Rubrum).

Perlakuan Rataan gram/ekor/hari $\quad$ Standar Deviasi

\begin{tabular}{lll}
\hline P0 & 60,13 & 4,69 \\
P1 & 61,51 & 2,69 \\
P2 & 61,64 & 1,28 \\
P3 & 59,32 & 1,98 \\
\hline
\end{tabular}

Besarnya rataan pertambahan bobot Ayam Broiler P0, P1, P2 dan P3 tidak berbeda nyata yaitu berturut - turut sebesar 60,13 gram, 61,51 gram, 61,64 gram dan 59,32 gram. Hasil ini menunjukan bahwa penambahan tepung jahe merah pada dosis 0,25\%-0,75\% tidak berpengaruh terhadap pertambahan bobot badan harian pada Ayam Broiler. Pertambahan bobot badan Ayam Broiler yang sama antar perlakuan diduga jumlah pemberian pakan dan konsumsi pada Ayam Broiler sama. Hal ini sesuai dengan pendapat Fadilah (2005), salah satu yang mempengaruhi pertambahan bobot badan ayam pedaging adalah jumlah pakan yang dikonsumsi dan terpenuhinya kebutuhan zat makanan ayam pedaging sama. Herawati dan Marjuki (2011), menyatakan bahwa penambahan tepung jahe merah memberikan pengaruh pada pertambahan bobot badan pada Ayam Broiler, di dalam jahe merah mengandung gingirol yang mampu menurunkan kadar lemak tubuh dan kolestrol pada ayam. 


\section{Pengaruh Perlakuan Terhadap Konversi Pakan}

Penambahan tepung jahe merah (Zingiber officinale var Rubrum) pada pakan Ayam Broiler tidak berpengaruh nyata $(\mathrm{P}>0,05)$ terhadap konversi pakan. Besarnya koversi pakan ayam yang mendapat perlakuan P0, P1, P2 dan P3 tersaji pada tabel 4.

Tabel 4. Konversi Pakan Ayam Broiler dengan Penambahan Tepung Jahe Merah.

\begin{tabular}{ccc}
\hline Perlakuan & Rataan/ekor/hari & Standar Deviasi \\
\hline P0 & 2,16 & 0,15 \\
P1 & 2,19 & 0,19 \\
P2 & 2,06 & 0,02 \\
P3 & 2,15 & 0,07 \\
\hline
\end{tabular}

Besarnya konversi pakan Ayam Broiler P0, P1, P2 dan P3 tidak berbeda nyata yaitu berturut-turut sebesar 2,16; 2,19; 2,06 dan 2,15. Hasil ini menunjukan bahwa penambahan tepung jahe merah pada dosis $0,25 \%-0,75 \%$ tidak berpengaruh terhadap konversi pakan pada Ayam Broiler. Nilai konversi pakan yang sama antar perlakuan diduga karena besarnya PBBH yang sama dan konsumsi pakan yang sama. Nilai konversi pakan tergantung pada kualitas pakan yang diberikan, kecukupan nutrisi untuk memenuhi kebutuhan hidup pokok, pertumbuhan dan fungsi tubuh yang lain (Sudarto, et al., 2007).

Konversi pakan dipengaruhi oleh tingkat konsumsi pakan, daya cerna dan gizi pakan yang seimbang. Hal ini sesuai dengan pendapat Krista et al (2010) bahwa semakin tinggi konversi pakan, artinya semakin rendah tingkat efisiensinya. Dengan demikian berdasarkan analisis statistik, peningkatan konversi pakan yang terjadi membuat pertumbuhan ayam semakin terhambat sehingga pertambahan bobot badan yang diperoleh tidak dapat mengalami peningkatan yang maksimal. Minyak astiri pada jahe merah diduga mampu mengontrol $\mathrm{pH}$ yang sesuai untuk aktivitas enzim pencernaan. Pengaruh yang nyata dari mekanisme tersebut adalah perbaikan konversi pakan Ayam Broiler, pencernaan nutrien pakan dalam tubuh, serta berpengaruh positif terhadap metabolisme nitrogen, asam amino, dan glukosa (Ulfah, 2005).

\section{KESIMPULAN}

Penambahan tepung jahe merah (Zingiber officinale var Rubrum) dari level 0,25\%0,75\% dalam pakan Ayam Broiler tidak berpengaruh terhadap konsumsi pakan, pertambahan bobot badan dan konversi pakan.

\section{DAFTAR PUSTAKA}

Direktorat Jendral Peternakan Dan Kesehatan Hewan. 2019. Statistik Peternakan Dan Kesehatan Hewan. Kementrian Pertanian. Jakarta.

Fadilah. 2005. Panduan Mengelola Peternakan Ayam Broiler Komersial. Agromedia. Pustaka. Jakarta.

Furqon. 1999. Statistika Terapan Untuk Penelitian. Bandung: Alfabeta. 
Herawati. 2006. Pengaruh Penambahan Fitobiotik Jahe Merah (Zingiber Officinale Ros) terhadap Produksi dan Profil Darah Ayam Broiler. Fakultas Peternakan Universitas Muhammadiyah Purworejo.

Herawati. 2010. The effect of feeding red ginger as phytobiotic on body weight gain, feed covertion and internal organs condition of broiler. International Journal of Poultry Science 9(10): 963-967.

Herawati dan Marjuki. 2011. The Effect of Feeding Red Ginger (Merah (Zingiber Officinale Ros) as phytobiotic on Broire Slaughter Weight and Meat Quality. Int. J. Poult. Sci. 10(12): 983-985.

Kateran, P.P. 2010. Kebutuhan Gizi Ternak Unggas di Indonesia. Wartazoa 20 (4): 172-177.

Moorthy, M., S. Ravi, M. Ravikumar, K. Viswanathan dan S. C. Litell. 2009. Ginger paper and curry leaf powder as feed additives in broiler diet. Poult. Sci. 8(8): 779-782.

PT. Japfa Comfeed Indonesia Tbk. 2020. Kandungan Nutrisi Pakan Merk Surya Feed SB 11 Super. Lampung.

Sudarto, Y. dan A. Siriwa. 2007. Ransum Ayam dan Itik. Cetakan IX. Penebar Swadaya. Jakarta.

Ulfah, M. 2005. Minyak Astiri Penakluk Bakteri Pathogen. Ilmiah Popular. Poultry Indonesia. Edisi No. 298: 50-52. 